\title{
Inactivating Mutations of Luteinizing Hormone $\beta$-Subunit or Luteinizing Hormone Receptor Cause Oligo-Amenorrhea and Infertility in Women
}

\author{
Ivo Jorge Arnhold ${ }^{a}$ Adriana Lofrano-Porto $^{b}$ Ana Claudia Latronico ${ }^{a}$ \\ a Unidade de Endocrinologia do Desenvolvimento, Laboratório de Hormônios e Genética Molecular, LIM/42, \\ Divisão de Endocrinologia, Hospital das Clinicas da Faculdade de Medicina da Universidade de São Paulo, \\ São Paulo, and ${ }^{b}$ Unidade de Endocrinologia, Hospital Universitário de Brasília, Faculdade de Medicina da \\ Universidade de Brasília, Brasília, Brazil
}

\section{Key Words}

Luteinizing hormone $\cdot$ Amenorrhea $\cdot$ Hypogonadism •

Infertility · Puberty

\begin{abstract}
Women harbouring inactivating mutations in luteinizing hormone (LH) beta subunit (LHB) or LH receptor (LHCGR) genes have similar clinical manifestations characterized by female external genitalia, spontaneous breast and pubic hair development at puberty, and normal or late menarche followed by oligo-amenorrhea and infertility. Oestradiol and progesterone levels are normal for the early to midfollicular phase, but do not reach ovulatory or luteal phase levels, confirming lack of ovulation. Notably, serum LH levels are low in patients with $L H B$ mutations and high in those with $L H C G R$ mutations, whereas follicle-stimulating hormone levels are normal or only slightly increased. Pelvic ultrasound has demonstrated a small or normal uterus and normal or enlarged ovaries with cysts. Women with $L H B$ mutations may be treated with hCG (human chorionic gonadotropin) or $\mathrm{LH}$, whereas those with mutations in $L H C G R$ are resistant. Lhb and Lhcgr knockout female mice are close phenocopies of the respective human mutations, and confirm that early follicular development, low levels of oestrogen production and theca cell development are independent of LH action, which
\end{abstract}

is necessary for ovulation. Although inactivating mutations in $\angle H B$ and $\angle H C G R$ are rare in comparison to other genetic and non-genetic causes of hypogonadism, they should be considered in the differential diagnosis of oligo-amenorrhea and infertility.

Copyright $\odot 2009$ S. Karger AG, Basel

\section{Introduction}

Luteinizing hormone (LH) and follicle-stimulating hormone (FSH) are pituitary gonadotropins directly involved in the integrated series of events that regulate normal sexual maturation and fertility. They belong to the family of glycoprotein hormones, which also includes thyroid-stimulating hormone and human chorionic gonadotropin (hCG) [1]. These hormones are heterodimers composed of a common $\alpha$-subunit and a specific $\beta$-subunit, each encoded by a separate gene [2]. The human LH $\beta$-subunit gene $(L H B)$ is located within a cluster of 7 highly homologous sequences in chromosome 19q13.3, including 5 non-coding pseudogenes [2]. It encodes a peptide that contains 121 amino acids, which is $82 \%$ homologous to $\beta$-hCG. Both LH and hCG bind to the same G-protein-coupled receptor, characterized by 7 transmembrane domains with a long extracellular length [1].

\section{KARGER}

Fax +41613061234 E-Mail karger@karger.ch www.karger.com
(C) 2009 S. Karger AG, Base

0301-0163/09/0712-0075\$26.00/0

Accessible online at:

www.karger.com/hre
Dr. Ivo Jorge Arnhold, Laboratório de Hormônios e Genética Molecular - LIM/42 Disciplina de Endocrinologia, Departamento de Clínica Médica, Hospital das Clínicas da Faculdade de Medicina da Universidade de São Paulo, Av. Enéas de Carvalho Aguiar 155 - PAMB - $2^{\circ}$ andar - Bloco 6, São Paulo, SP, CEP 05403-900 (Brasil)

Tel. +55 113069 7512, Fax +55 113069 7519, E-Mail iarnhold@usp.br 


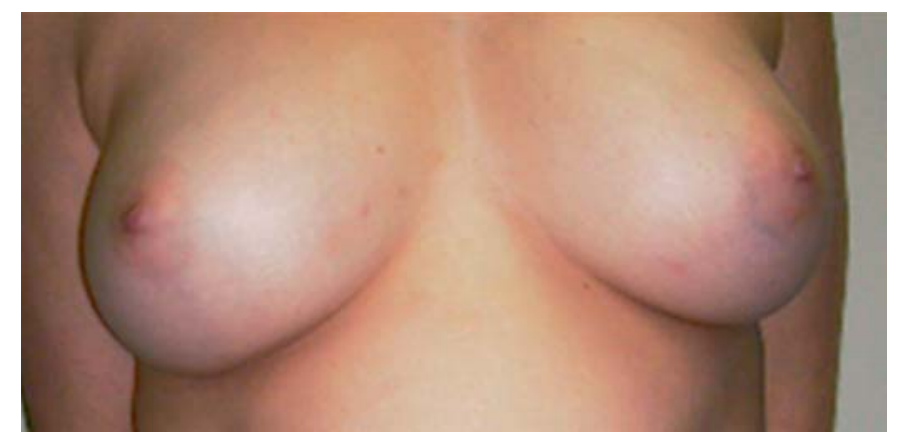

Fig. 1. Woman with $\mathrm{LH} \beta$-subunit mutation at 29 years of age. Complete breast development attained at puberty without hormonal replacement, revealing sufficient endogenous oestrogen secretion despite absence of $\mathrm{LH}$.

The human LH/CG receptor gene (LHCGR), located at chromosome 2p21, is composed of 11 exons. The largest exon, 11, codifies the entire transmembrane domain.

Naturally occurring inactivating mutations in the $L H B$ and $L H C G R$ genes are very rare, especially in females, but constitute a model providing insight into their physiological role in human reproduction. The first woman with a mutation in the $\mathrm{LH} \beta$-subunit was described only recently [3], where the phenotype resembled that of previously reported women with mutations in the $\mathrm{LH}$ receptor (table 1) $[4,5]$. Mutations in the genes that encode the gonadotropin subunits seem to be even more uncommon than those affecting the gonadotropin receptors. All female patients with $L H B$ or $L H C G R$ gene mutations reported to date are sisters of $46, \mathrm{XY}$ probands with the corresponding mutations in $\mathrm{LH}$ or its receptor. However, it is important to be able to recognize this phenotype in the absence of an affected male relative.

\section{Inactivating LH $\beta$-Subunit Mutations}

\section{Inactivating LH $\beta$-Subunit Mutations in $46, X Y$ \\ Subjects}

To date, at least 5 men with inactivating $L H B$ mutations from 4 different families have been reported [3, 68]. The phenotype included male external genitalia at birth, but absent pubertal development and severe testosterone deficiency and azoospermia during adulthood. The testicular histological hallmarks of selective LH deficiency in these men were absent or hypoplastic Leydig cells and spermatogenic arrest. Notably, the case with a Q54R mutation in $L H B$ had high immunoreactive $\mathrm{LH}$
Table 1. Characteristic features of women (46,XX) with inactivating mutations in $\mathrm{LH} \beta$-subunit or $\mathrm{LH}$ receptor

\begin{tabular}{|c|c|}
\hline External genitalia & female \\
\hline $\begin{array}{l}\text { Pubic hair and breast } \\
\text { development }\end{array}$ & normal \\
\hline Menstrual cycles & $\begin{array}{l}\text { normal to late menarche followed by } \\
\text { oligo-amenorrhea }\end{array}$ \\
\hline Fertility & $\begin{array}{l}\text { absence of ovulation ( } \mathrm{LHB} \text { mutations } \\
\text { may respond to hCG or } \mathrm{LH} \text { ) }\end{array}$ \\
\hline LH levels & $\begin{array}{l}\text { low in } L H B \text { and high in } L H C G R \\
\text { mutations }\end{array}$ \\
\hline FSH levels & normal to slightly high \\
\hline $\begin{array}{l}\text { Estradiol and } \\
\text { progesterone levels }\end{array}$ & low to normal for midfollicular phase \\
\hline Pelvic ultrasound & $\begin{array}{l}\text { small to normal uterus, normal to } \\
\text { enlarged ovaries with cysts }\end{array}$ \\
\hline Bone mineral density & low to normal \\
\hline
\end{tabular}

levels measured by radioimmunoassay, but low LH receptor-binding properties on radioreceptor assay [6]. Lofrano-Porto et al. [3] have recently identified 2 men homozygous for a mutation in the $5^{\prime}$ splice-donor site of intron 2 , IVS2 $+1 \mathrm{G} \rightarrow \mathrm{C}$, resulting in an abnormal mRNA incorporating the 236 nucleotides of intron 2 of $L H B$. Interestingly, the administration of chronic exogenous testosterone to these affected men resulted in a significant increase in testicular volume. This effect was attributed to the synergistic actions of high endogenous FSH levels and increasing levels of circulating testosterone, which may have contributed to the late proliferation of Sertoli cells and testicular growth [3].

\section{Inactivating $L H \beta$-Mutations in $46, X X$ Subjects}

The sister of these 2 men is the sole woman described so far who harbours an inactivating mutation in the $\mathrm{LH}$ $\beta$-subunit gene [3]. She had normal pubertal development and menarche at the age of 13 years, followed by oligomenorrhea for 14 years of her life. At the age of 29, her breasts (fig. 1) and uterus were completely developed (uterine volume: $50 \mathrm{ml}$; normal range, $30-90 \mathrm{ml}$ ). Ovaries were of normal or slightly enlarged size $(7$ and $10 \mathrm{ml}$, normal 3-9 ml; fig. 2) and had a multicystic appearance, a finding consistent with the growth of multiple small follicles induced by FSH. Serum LH concentrations were undetectable both at baseline and after stimulation with 


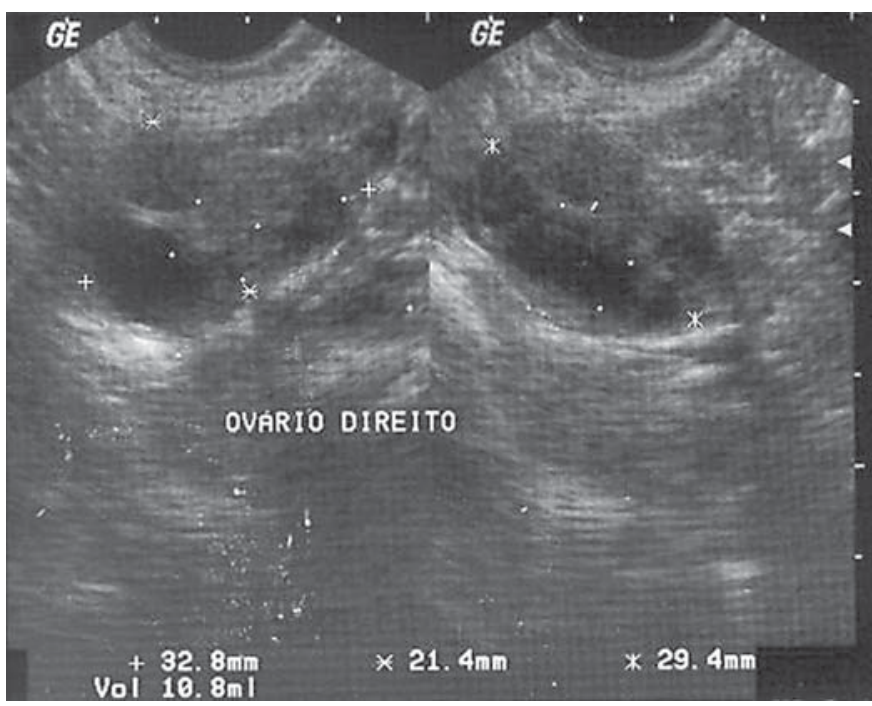

Fig. 2. Enlarged ovary with large cysts in a woman with LH $\beta$ subunit mutation.

gonadotropin-releasing hormone, whereas FSH concentrations $(4.8 \mathrm{IU} / \mathrm{l})$ were normal. Repeated measurements of serum oestradiol (29-44 pg/ml) and progesterone $(0.44$ $\mathrm{ng} / \mathrm{ml}$ ) showed levels within the low-to-normal range for the follicular phase. Serum inhibin B level was high, further strong evidence for the presence of healthy early antral follicles in her ovaries. This Brazilian woman was found to harbour the same homozygous mutation in a non-coding intronic sequence affecting a 5 ' splice-donor site of the $L H B$ gene (IVS2 $+1 \mathrm{G} \rightarrow \mathrm{C}$ ). A G $\rightarrow$ C substitution at position +1 of intron 2 of the $L H B$ gene severely disrupted the splicing of the $L H B$ mRNA, resulting in an exon 3 frameshift, consequently generating an aberrant transcript [3] (fig. 3).

Following supplementation with oestrogen, a dominant follicle of $18 \mathrm{~mm}$ was evident on ultrasonography, but ovulation remained impaired and no corpus luteum was identified. Interestingly, after 10 days of combined oestrogen-progestagen treatment, a functional follicular cyst measuring $44 \mathrm{~mm}$ in diameter was formed. Taken together, these findings corroborate the knowledge that female pubertal development may occur normally in the absence of $\mathrm{LH}$ action, reinforcing the main actions of $\mathrm{LH}$ on the induction of ovulation and corpus luteum formation. Furthermore, the formation of a dominant follicle after supplementation with oestrogen only may indicate that $\mathrm{LH}$ activity is not necessary until the early preovulatory stage of follicular development. This finding suggests that oestrogen or oestrogen-related factors were suf-

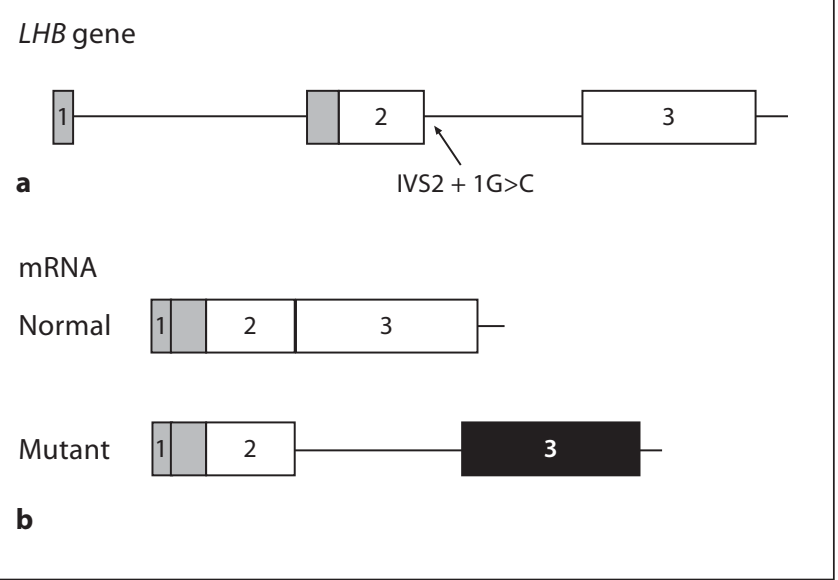

Fig. 3. a Schematic representation of the $L H B$ gene, showing the IVS2 $+1 \mathrm{G} \rightarrow \mathrm{C}$ mutation. $\mathbf{b}$ Normal and mutant mRNA, resulting from the retention of the intron 2 and exon 3 frameshift. Numbers = exons; open bars = translated regions; gray bars = untranslated regions; black bar $=$ frameshift.

ficient to induce dominant follicular growth up, until this stage, in the presence of preserved FSH secretion and a normal ovarian environment, as observed in the LH-deficient woman [3].

\section{Inactivating LH Receptor Mutations}

\section{Inactivating LH Receptor Mutations in 46,XY Subjects}

In genetic males, severe homozygous inactivating mutations of the LH receptor (LHCGR) cause 46, XY disorders of sex development, previously referred to as male pseudohermaphroditism $[4,9,10]$, whereas milder mutations result in hypospadias and/or micropenis and hypogonadism [4, 11-13]. In the absence of androgen action during human fetal development, the external genitalia remain female, irrespective of chromosomal or gonadal sex. hCG and LH bind to the same LHCGR at testicular Leydig cells. During the first trimester of gestation, hCG, by stimulating the LHCGR, is fundamental for secretion of testosterone and development of the male external and internal genitalia. Most inactivating mutations of LHCGR result in reduced or absent testosterone secretion and consequent impairment of masculinization of the external genitalia [14]. Interestingly, a deletion of exon 10 of $L H C G R$ has been described, resulting in a phenotype of hypogonadism in a man with normal male external genitalia. In vitro, the LHCGR with this deletion responded normally to hCG, but not to $\mathrm{LH}$, explaining 
Fig. 4. a Schematic representation of the LHCGR gene, showing inactivating mutations found in women. b Schematic representation of the LHCGR structure, and location of the mutations identified in women.

\section{LHCGR gene}
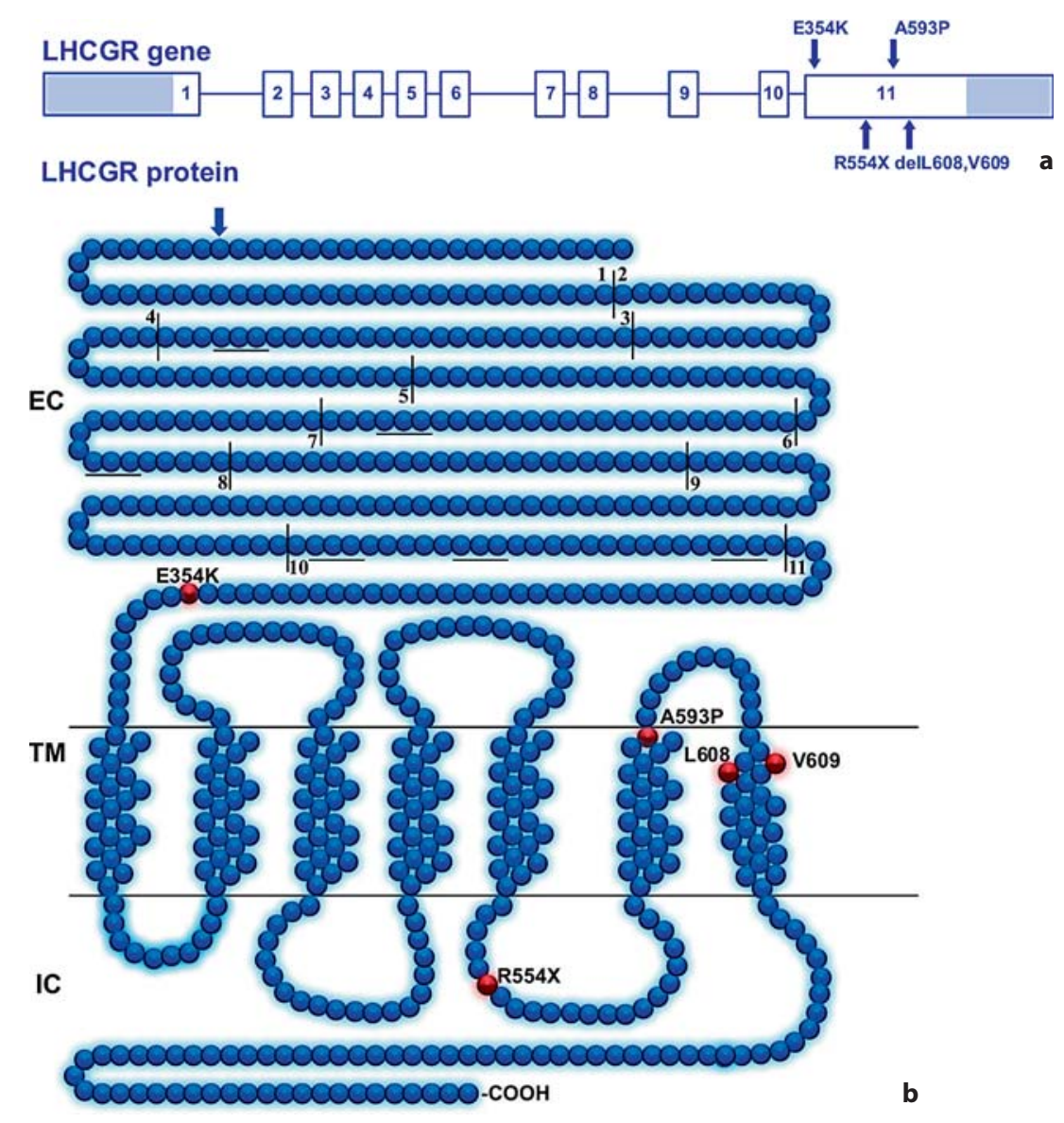

the peculiar phenotype while revealing that exon 10 of the LHCGR is responsible for specificity of LH binding $[15,16]$.

Recently, Kossack et al. [17] identified a novel cryptic exon of the human LHCGR (exon 6A). In 3 patients with Leydig cell hypoplasia, sequencing of this exon revealed mutations, which in functional studies resulted in generation of predominantly non-functional LHCGR.

The clinical findings of the selective LH-deficient hypogonadal men contrast with the feminizing or ambiguous appearance of the external genitalia observed at birth in $46, \mathrm{XY}$ subjects harbouring inactivating mutations in the LHCGR. Furthermore, these 2 human models of genetic diseases corroborate important concepts in the physiology of sexual development. First, fetal testosterone secretion may occur independently of $\mathrm{LH}$, but is absolutely dependent on placental hCG secretion and the integrity of the LH receptor. Second, the predominant action of LH is on testicular Leydig cell maturation and testosterone secretion after puberty.

\section{Inactivating LH Receptor Mutations in 46,XX}

Subjects (fig. 4)

Four unrelated women with different mutations in LHCGR have been reported: a stop codon R554X resulting in a truncated receptor at the level of the third intracellular loop [4], a deletion of 2 amino acids, L608 and V609, in the seventh transmembrane helix [18], and 2 missense mutations, A593P [19] in the sixth transmembrane segment and E354K in the extracellular domain of LHCGR [20]. All patients were ascertained because they were sisters of probands with 46,XY disorders of sex development caused by severe mutations in LHCGR. 


\section{Clinical Characteristics}

These 46,XX subjects were studied at ages ranging from 16 to 40 years. All had female external genitalia and spontaneous normal pubic hair and breast development at puberty (table 1). Menarche occurred spontaneously in 3 patients at between 12 and 20 years of age and was followed by menses at variable intervals, ranging from 3 weeks to 15 months, but predominantly at intervals of several months $[4,18,19]$. In the youngest patient, menarche was induced at the age of 16 years [20]. The patients responded to progesterone administration and withdrawal with uterine bleeding, except for the patient with the R554X mutation during low oestradiol levels $(<10-25$ $\mathrm{pg} / \mathrm{ml}$ ) [4]. Two patients tried to conceive for at least 1.5 years without success $[4,18]$.

\section{Hormonal Levels and Pelvic Ultrasound}

Serum LH was high in all patients (10-38 IU/1, normal 0.95-8.4), whereas serum FSH was normal or only slightly increased (6.3-11.5 IU/l, normal 2.4-9.3), resulting in a high LH/FSH ratio. Two patients had a gonadotropinreleasing hormone test and responded with high LH peak levels. Oestradiol levels ranged from $<10$ to $122 \mathrm{pg} / \mathrm{ml}$, but were usually lower than $50 \mathrm{pg} / \mathrm{ml}$, levels normally found in the early and mid-follicular phase. Progesterone levels ranged from $<0.1$ to $1.2 \mathrm{ng} / \mathrm{ml}$. Serum prolactin and androgen levels (testosterone, androstenedione, 17hydroxyprogesterone, DHEA, DHEA-S) were all normal $[4,18-20]$.

Uterine volume on pelvic ultrasound ranged from 9 to $70 \mathrm{ml}$ (normal adult $30-90 \mathrm{ml}$ ), and was low in 2 patients and normal in the other 2 patients. Ovarian volume ranged between 3.3 and $22 \mathrm{ml}$ (normal adult 3-9 $\mathrm{ml}$ ), according to the development of cysts that reached up to 55 $\mathrm{mm}$ in diameter. Compared to normal women, these patients had lower oestradiol levels despite having larger follicular cysts, indicating reduced steroidogenic efficiency of the follicles. The insufficient oestrogen production was corroborated by the high LH levels, indicating inadequate feedback at the hypothalamic-pituitary unit $[4,18-20]$.

Ovarian biopsy in 1 patient revealed multiple primordial follicles, preantral follicles with oocytes and few granulosa cell layers, and follicles with a large antrum and well-developed theca cell layer. In these antral follicles, the theca cells had a luteinized appearance, whereas the granulosa cells in the same follicle did not show signs of luteinization. No preovulatory follicles, corpora lutea or corpora albicans were present [19].
Bone density, available in 3 patients, was low in 2 [4, 19] and normal in 1 patient [18], and was in accordance with oestrogen production.

\section{Topography and Structure-Function of LH Receptor Mutations}

One Brazilian patient was homozygous for the R554X mutation predicting a truncation of the LHCGR at the third intracellular loop, and eliminating a large portion of the receptor [4]. This patient had the most severe phenotype from among the patients reported with LH receptor mutations: late menarche (20 years), long periods of amenorrhea ( $>15$ months), lowest oestradiol levels, smallest uterus and presence of osteoporosis. The R554X mutation abolishes a restriction site for the enzyme TaqI (TCGA $\rightarrow$ TTGA), allowing rapid screening for this mutation. More recently, another Brazilian family with this mutation, including XY and XX patients with similar phenotypes, was studied (unpublished data).

Another Brazilian patient had a homozygous single nucleotide change of $\mathrm{G} \rightarrow \mathrm{C}$ at position 1787 of LHCGR resulting in substitution of proline for alanine at codon 593 at the border of the sixth transmembrane segment and third intracellular loop of the receptor molecule [19]. During in vitro experiments, human embryonic kidney 293 cells transfected with mutant LHCGR expression plasmid failed to produce cAMP when treated with hCG, in contrast to those transfected with wild-type LHCGR [19].

A third Brazilian patient was found to have a homozygous deletion of the 6 nucleotides $1822-1827$ of the LHCGR gene, resulting in the deletion of amino acids leucine 608 and valine 609 within the seventh transmembrane helix [18]. Transfection of 293 cells with mutant LHCGR revealed diminished receptors at the cell surface as well as increased intracellular retention of the LHCGR. In spite of the decreased cell surface expression, binding assays were possible, and showed that the mutant receptor had normal binding affinity, but low cAMP production, when stimulated by hCG [18].

The fourth patient had a homozygous substitution of $\mathrm{A} \rightarrow \mathrm{G}$ at position 1060 of the LHCGR gene resulting in change of codon 354 from glutamic acid to lysine [20]. This mutation is located in the extracellular domain of the receptor, adjacent to the first transmembrane domain. Using in vitro mutagenesis-transfection analysis, the E354K mutation caused complete loss of receptor function, as indicated by the failure of cAMP production after hCG stimulation [20]. 


\section{Comparison between Women with LHB and LHCGR} Mutations

In contrast to $46, \mathrm{XY}$ patients, in whom inactivating mutations in $L H B$ or $L H C G R$ result in phenotypes so distinct at birth as to lead to different sex of rearing, the phenotypes of 46,XX patients with $L H B$ and LHCGR mutations are very similar. The small number of cases reported to date does not permit conclusions to be drawn from the very subtle differences. A major difference, however, is the low bioactive LH levels in patients with LHB mutations and high LH levels in those with LHCGR mutations. Accordingly, women with $L H B$ mutations may be treated with exogenous LH or hCG, whereas women with LHCGR mutations are resistant to $\mathrm{LH}$ and, at present, no treatment is effective in rescuing their fertility $[3,4,18$ 20].

Interestingly, four of the five $46, \mathrm{XX}$ patients with $L H B$ or LHCGR mutations are from Brazil, in contrast to a broader geographical distribution of $46, \mathrm{XY}$ patients with LHCGR mutations. This might be a consequence of the greater awareness of this condition, as well as frequent larger sibship sizes in Brazil [3, 4, 18-20].

In genetic males, severe mutations in LHCGR cause $46, \mathrm{XY}$ disorders of sex development with ambiguous genitalia, whereas milder mutations cause micropenis and hypergonadotropic hypogonadism. To date, only sisters of 46,XY patients with severe LHCGR mutations have been reported. The phenotypes caused by mutations in $L H B$ and $L H C G R$ in women are milder than in men, suggesting that 46 ,XX patients with yet to be reported milder LHCGR mutations will have an even milder phenotype than the women described above.

\section{Animal Models}

There are no reports of naturally occurring inactivating mutations of LH $\beta$-subunit or LH receptor in animals. However, female mice with knockout of both $L h b$ and Lhcgr have been produced, and yielded very similar phenotypes to those of the human mutations.

\section{LH $\beta$-Subunit Knockout Mice}

$\mathrm{Ma}$ et al. [21] produced female knockout mice lacking the hormone-specific LH $\beta$-subunit. Mutant mice were hypogonadal with small ovaries and thin uteri. Histological analysis of the ovaries from adult mutants revealed the absence of healthy antral preovulatory follicles and corpora lutea, confirming impaired oestrous cycles. Although primary and secondary follicles appeared normal, many antral follicles looked abnormal, collapsing with degenerating oocytes. Occasionally, non-hemor- rhagic cysts in some of the ovary sections were observed. Although granulosa cells looked abnormal in many degenerating antral follicles, a prominent thecal cell layer was present in multiple follicles at different stages of progression. Within the ovary, LH acts on thecal cells that express LH receptors. Expression analysis indicated that thecal differentiation markers, including LH receptor, Bmp4, and Cyp17a1, were all expressed in the null ovaries. This finding confirms that differentiation of thecal layer was not impaired in the absence of LH. Although an intact theca was present in the mutant ovary, expression of many genes encoding steroid biosynthesis enzymes, including Cyp11al, Cyp19a1 and Cyp17al, were reduced. Additionally, expression of cyclooxygenase 2, a marker for ovulation, was also reduced in the null ovary. Consistent with these defects in steroidogenic markers, serum oestradiol and progesterone levels were both lower in the adult null females compared with those in wild-type controls. The defects were not secondary to aberrant FSH regulation because FSH levels were unaffected in null mice. Finally, both male and female null mice were able to be pharmacologically rescued by exogenous hCG [21].

\section{LH Receptor Knockout Mice}

Lhcgr knockout female mice were independently generated by Zhang et al. [22] (LuRKO mice) and Lei et al. [23]. Compared to wild-type, the age of vaginal opening was delayed, ovaries were reduced in size and uteri were significantly thinner in adult LuRKO mice. Ovarian histology showed presence of follicles up to the early antral stage, but no preovulatory follicles or corpora lutea. No apparent differences were seen in the thickness of the theca cell layers surrounding the developing follicles [22]. In contrast, the ovaries of the gonadotropin-deficient $h p g$ mice have follicles up to the preantral stage [24], which indicates that the FSH action present in LuRKO mice has a distinct effect on progression of preantral follicles up to the early antral stage. Correspondingly, the lack of preovulatory follicles and corpora lutea indicates that the very last steps of follicular maturation, as well as ovulation, do not occur without LH action. Another intriguing feature of the LuRKO ovaries was the apparent normal thickness of thecal cell layers surrounding the follicles. Hence, although theca cells are a target of LH action, their survival is apparently not dependent on LH, an observation which can also be made in $h p g$ ovaries [24]. Low but detectable levels of P450 17-OH mRNA, a marker of theca cell steroidogenesis [25], were detected in the LuRKO ovaries, indicating that this enzyme is also expressed constitutively at low levels. This finding, together 
with the well-developed theca cells and low but detectable oestradiol level of the LuRKO ovaries, explains the delayed vaginal opening of the LuRKO females. Female LuRKO mice represent close phenocopies of the respective human mutation [22].

\section{Conclusions}

In conclusion, women with mutations in LH $\beta$-subunit or LH receptor have similar phenotypes characterized by female external genitalia, spontaneous breast and pubic hair development at puberty, normal or late menarche followed by oligo-amenorrhea and infertility. Serum $\mathrm{LH}$ levels are low in patients with $L H B$ mutations and high in those with LHCGR mutations, whereas FSH levels are normal or only slightly increased. Oestradiol and progesterone levels are normal for the early to midfollicular phase, but do not reach ovulatory or luteal phase levels, confirming lack of ovulation. Prolactin and androgen levels are normal. Pelvic ultrasound examination demonstrated small or normal uterus and normal or en- larged ovaries with cysts. Lhb and Lhcgr knockout female mice are close phenocopies of the respective human mutations and confirm that early follicular development, low levels of oestrogen production and theca cell development are independent of $\mathrm{LH}$ action, which is necessary for ovulation. Finally, women with mutations in $L H B$ mutations may be treated with hCG or LH, whereas those with mutations in LHCGR are resistant. Mutations in $L H B$ and $L H C G R$ are rare in comparison to other genetic and non-genetic causes of hypo- and hypergonadotropic hypogonadism which result in similar phenotypes. However, it is important to keep these conditions in mind in the differential diagnosis of oligo-amenorrhea and infertility.

\section{Acknowledgements}

This work was partially funded by Grants from Fundação de Amparo a Pesquisa do Estado de São Paulo 05/04726-0 and Conselho Nacional de Desenvolvimento Científico e Tecnológico (CNPq) to I.J.P.A. (300938/06-3) and A.C.L. (300469/2005).

\section{References}

1 Ascoli M, Fanelli F, Segaloff DL: The lutropin/choriogonadotropin receptor, a 2002 perspective. Endocr Rev 2002;2:141-174.

2 Themmen APN: An update of the pathophysiology of human gonadotrophin subunit and receptor gene mutations and polymorphisms. Reproduction 2005;130:263274.

$\checkmark 3$ Lofrano-Porto A, Barra GB, Giacomini LA, Nascimento PP, Latronico AC, Casulari LA, da Rocha Neves Fde A: Luteinizing hormone beta mutation and hypogonadism in men and women. N Engl J Med 2007;357:897904.

$\checkmark 4$ Latronico AC, Anasti J, Arnhold IJP, Rapaport R, Mendonca BB, Bloise W, Castro M, Tsigos C, Chrousos GP: Testicular and ovarian resistance to luteinizing hormone caused by homozygous inactivating mutations of the luteinizing hormone receptor gene. N Engl J Med 1996;334:507-512.

$\checkmark 5$ Arnhold IJ, Latronico AC, Batista MC, Izzo CR, Mendonca BB: Clinical features of women with resistance to luteinizing hormone. Clin Endocrinol (Oxf) 1999;51:701-707.

6 Weiss J, Axelrod L, Whitcomb RW, Harris PE, Crowley WF, Jameson JL: Hypogonadism caused by a single amino acid substitution in the $\beta$ subunit of luteinizing hormone. N Engl J Med 1992;326:179-183.
Valdes-Socin H, Salvi R, Daly AF, Gaillard RC, Quatresooz P, Tebeu PM, Pralong FP, Beckers A: Hypogonadism in a patient with a mutation in the luteinizing hormone betasubunit gene. N Engl J Med 2004;351:26192625.

8 Daly AF, Salvi R, Menage J, Thiry A, Pralong F, Gaillard R, Beckers A: Identification of a family harboring a novel LH beta-subunit mutation associated with hypogonadism. Abstracts 88th Annu Meet Endocr Soc, Boston, 2006.

$\checkmark 9$ Kremer H, Kraaij R, Toledo SPA, Post M, Fridman JB, Hayashida CY, van Reen M, Milgrom E, Ropers HH, Mariman E, Themmen APN, Brunner HG: Male pseudohermaphroditism due to a homozygous missense mutation of the luteinizing hormone receptor gene. Nat Genet 1995;9:160-164.

$>10$ Laue L, Wu SM, Kudo M, Hsueh AJW, Cutler GB Jr, Griffin JE, Wilson JD, Brain C, Berry AC, Grant DB, Chan WY: A nonsense mutation of the human luteinizing hormone receptor gene in Leydig cell hypoplasia. Hum Mol Genet 1995;4:1429-1433.

11 Laue LL, Wu SM, Kudo M, Bourdony CJ, Cutler GB Jr, Hsueh AJW, Chan WY: Compound heterozygous mutations of the luteinizing hormone receptor gene in Leydig cell hypoplasia. Mol Endocrinol 1996;10:987997.
12 Misrahi M, Meduri G, Pissard S, Bouvattier C, Beau I, Loosfelt H, Jolivet A, Rappaport R, Milgrom E, Bougneres P: Comparison of immunocytochemical and molecular features with the phenotype in a case of incomplete male pseudohermaphroditism associated with a mutation of the luteinizing hormone receptor. J Clin Endocrinol Metab 1997;82: 2159-2165.

13 Martens JWM, Verhoef-Post M, Abelin N, Ezabella M, Toledo SPA, Brunner HG, Themmen APN: A homozygous mutation in the luteinizing hormone receptor causes partial Leydig cell hypoplasia: correlation between receptor activity and phenotype. Mol Endocrinol 1998; 12:775-783.

14 Huhtaniemi I, Alevizaki M: Gonadotrophin resistance. Best Pract Res Clin Endocrinol Metab 2006;20:561-576.

15 Gromoll J, Eiholzer U, Nieschlag E, Simoni M: Male hypogonadism caused by homozygous deletion of exon 10 of the luteinizing hormone (LH) receptor: differential action of human chorionic gonadotropin and LH. J Clin Endocrinol Metab 2000;85:2281-2286.

16 Müller T, Gromoll J, Simoni M: Absence of exon 10 of the human luteinizing hormone (LH) receptor impairs $\mathrm{LH}$, but not human chorionic gonadotropin action. J Clin Endocrinol Metab 2003;88:2242-2249. 
-17 Kossack N, Simoni M, Richter-Unruh A, Themmen APN, Gromoll J: Mutations in a novel, cryptic exon of the luteinizing hormone/chorionic gonadotropin receptor gene cause male pseudohermaphroditism. PLoS Med 2008;5:e88.

-18 Latronico AC, Chai Y, Arnhold IJP, Liu X, Mendonca BB, Segaloff DL: A homozygous microdeletion in helix seven of the luteinizing hormone receptor associated with familial testicular and ovarian resistance is due to both decreased cell surface expression and impaired Gs activation by the cell surface receptor. Mol Endocrinol 1998;12:442-450.

-19 Toledo SPA, Brunner HG, Kraaij R, Post M, Dahia PLM, Hayashida CY, Kremer H, Themmen APN: An inactivating mutation of the luteinizing hormone receptor causes amenorrhea in a 46,XX female. J Clin Endocrinol Metab 1996;81:3850-3854.
20 Stavrou SS, Zhu YS, Cai LQ, Katz MD, Herrera $\mathrm{C}$, Defillo-Ricart $\mathrm{M}$, Imperato-McGinley J: A novel mutation of the human luteinizing hormone receptor in 46XY and 46XX sisters. J Clin Endocrinol Metab 1998;83: 2091-2098.

21 Ma X, Dong Y, Matzuk MM, Kumar TR: Targeted disruption of luteinizing hormone beta-subunit leads to hypogonadism, defects in gonadal steroidogenesis, and infertility. Proc Natl Acad Sci USA 2004;101:1729417299.
22 Zhang FP, Poutanen M, Wilbertz J, Huhtaniemi I: Normal prenatal but arrested postnatal sexual development of luteinizing hormone receptor knockout (LuRKO) mice. Mol Endocrinol 2001;15:172-183.

23 Lei ZM, Mishra S, Zou W, Xu B, Foltz M, Li $\mathrm{X}$, Rao CV: Targeted disruption of luteinizing hormone/human chorionic gonadotropin receptor gene. Mol Endocrinol 2001;15: 184-200.

24 Cattanach BM, Iddon CA, Charlton HM, Chiappa SA, Fink G: Gonadotrophin-releasing hormone deficiency in a mutant mouse with hypogonadism. Nature 1977;269:338340 .

25 Elvin JA, Yan C, Wang P, Nishimori K, Matzuk MM: Molecular characterization of the follicle defects in the growth differentiation factor 9-deficient ovary. Mol Endocrinol 1999;13:1018-1034. 